\title{
Ensuring the Growth of Enterprises and Organizations through the Motivation of Managerial Staff
}

\begin{abstract}
Submitted 02/02/20, $1^{\text {st }}$ revision 28/02/20, $2^{\text {nd }}$ revision 23/03/20, accepted 12/04/20
\author{
O.A. Khytrova ${ }^{1}$, I.M. Sysoieva ${ }^{2}$, H.V. Dolha ${ }^{3}$, \\ V.O. Peniuk ${ }^{4}$, O.V. Motuzenko ${ }^{5}$
}

Abstract:

Purpose: The article studies the motivational issues of managerial staff in the context of ensuring the growth of enterprises and organizations.

Design/Methodology/Approach: Eurostat data have been used within the framework of the disclosure of the article. Such methods of economic analysis as generalization and comparison have been applied for processing statistical data.

Findings: It has been established that in the countries of European Union, such as Great Britain, Spain, Germany, Poland and France, there is an acceptable, in particular high level of satisfaction of their own job by employed persons, including managerial employees (managers). It has been established, that timely identification and diagnosis of problematic situations that arise on the path of development and growth of enterprises and organizations substantially depends on the level of qualification and professionalism of the head, that is, the manager.

Practical Implications: The results are interesting from the theoretical and practical aspects to be applied for the improvement of the motivation to employees, including managerial staff at the enterprises and organizations.

Originality/Value: The insight of the article's subject matter requires an analysis of such key indicators as the occupational level, population's education index, individual level of the population's digital skills, the proportion of people who speak a foreign language, the proportion of people employed and at the same time are satisfied with their job.
\end{abstract}

Keywords: Motivation, managerial staff, enterprise, organization, development.

JEL codes: L51, Q12, M20, M54.

Paper type: Research article.

\footnotetext{
${ }^{1}$ Department of Management and Tourism, Faculty of Management, Service Industry and Catering Technologies, Chernivtsi Trade and Economic Institute Kiev National University of Trade and Economics, Chernivtsi, Ukraine; E-mail: olga_hitrova@ukr.net

${ }^{2}$ Department of Economy, Account and Taxation, Vinnytsya Educational-Scientific Institute of Economy of the Ternopil National Economic University, Vinnytsia, Ukraine,

E-mail: innas1853@gmail.com

${ }^{3}$ As in 1 E-mail: dolga.galina1985@gmail.com

${ }^{4}$ As in 1 E-mail: margusha23@yahoo.com

${ }^{5}$ PJSC “Insurance company "Persha”, Kyiv, Ukraine; E-mail: omotuzenko@gmail.com
} 


\section{Introduction}

A study of global trends in entrepreneurship development shows that in order to ensure the growth of enterprises and organizations, special attention should be paid to the motivation issues of managerial staff. At the same time, the practice of functioning of modern enterprises and organizations reveals that the timely identification and diagnosis of problematic situations, arising in the way of development and growth of many enterprises and organizations, depends on the level of qualification and professionalism of the administrator (manager). Whereas, the success of the manager's activity is shaped under the pretext of his ability to combine personal qualities and implement them into the decision-making process of management.

Therefore, in the context of ensuring the effective functioning and long-term growth of enterprises and organizations, it is necessary first, to solve the problematic issues of motivation of the administrator.

\section{Theoretical Background}

Key principles of managerial staff's motivation in the context of enterprise and organization growth are presented in researches of many world's leading scientists. Consequently, Delmar and Wiklund (2008) have investigated the effects of motivation on manager's career advancement. In addition, scientists have come to the conclusion that the motivated manager effectively controls the activity of the enterprise, and thus, affects the improvement of business results.

Gillan et al. (2010) have analyzed peculiarities of work activity motivation at enterprises, operating in environmental, social and management spheres. According to the results of the analysis, scientists have come to the conclusion that managers, including administrators, are more careful about the values, including the costs of the enterprise, in contradistinction from the shareholders of the enterprise, despite the fact that their salaries are significantly lower than the shareholders' ones (Gillan et al., 2010).

However, Maslen and Hopkins (2014) have investigated the motivation features of managers, working in hazardous areas of activity. Therefore, scientists have identified the role of incentives that are designed to manage a number of high-risk accidents occurrence in hazardous areas of activity. It has been established that managers need to be motivated not only to obtain business and financial results of the enterprise, but also to ensure the safety of this activity in the context of preventing the occurrence of various kinds of accidents (Maslen and Hopkins, 2014).

Ke et al. (2012) consider that two leverage values that can cause internal motivation of managers at the enterprise:

1) autonomous design of workplaces; 
2) tactics of socialization.

The scientists also prove in their studies that intrinsic motivation is manifested through normative motivation (inclines towards the idea that technology allows to obtain a number of external benefits, namely fulfillment of tasks, increasing the level of labor productivity and hedonic motivation providing the pleasure of using technologies (Ke et al., 2012).

Rusetski (2011) has examined the cultural and procedural factors that influence the motivation of business executives. The study has found that an important factor that reduces the level of manager's motivation is the strategic orientation of technologies. However, customer orientation of the enterprise and cultural disregard of the classical management principles only increase the motivation of managers. According to the scientist's conclusion, the influence of cultural factors remains more effective in motivating managers than carrying out an appropriate assessment of the manager's activities or providing him with compensatory payment (Rusetski, 2011).

At the same time, Chromjakova (2016) has presented the main motivation criteria that the manager should possess. In particular, these include:

$>$ a focused concentration on achieving the goals and implementing the targets of the enterprise;

$>$ making of considered and reasonable management decisions;

$>$ good relationships with the team;

$>$ creative thinking and innovative approaches to solving problems, etc. (Chromjakova, 2016).

In the framework of the mentioned above, Li (2015) believes that the incentive for the head of the enterprise should be carried out on the basis of the theory of emergency situations. In turn, the use of one or another incentive for the head should first, depends on the level of education of the administrator and whether the manager is a high-qualified employee. At the same time, the research of $\mathrm{Li}$ (2015) has shown that generally the manager wants to see the independence of his own capabilities as an incentive, while the demand for financial incentives is not so important.

Paglis and Green (2002) have developed a leadership model based on the criteria for motivating managers to achieve leadership positions at the enterprise. The basic features of this process iclude:

$>$ determining the promising direction of the future manager's activity;

$>$ strengthening the position of the manager's supporters;

$>$ elimination of existing and potential obstacles that arise in the way of strengthening leadership positions ( Paglis and Green, 2002). 
Herewith, Schmid Mast et al. (2010) argue that one of the key elements in the effectiveness of a head's leadership position is his or her strong motivation, which is directly related to the dominance of the manager as an individual. At the same time, Wziatek-Stasko (2016) remarks that managers' motivation is a key indicator of determining the quality of their leadership.

In the context of the topic insight of the scientific article, it should be noted that Buble et al. (2014) have analyzed the relationship between the leadership style applied at the enterprise and the motivation of the head, which encourages him to achieve goals and objectives of enterprise activities. In the course of the research, scientists have come to the conclusion that the manager's occupation of a position in the upper echelons of the enterprise management system requires the manager to have significant work experience (at least 10-15 years) and the necessary level of education. Despite this, it has been established that the motivation of managerial staff is divided into two parts:

$>$ internal motivation, which reflects the methods of incentive to the manager's activities in accordance with the complexity of his / her work;

$>$ external motivation, which reflects the level of satisfaction of the manager with his / her working conditions and salary through the means of inducing (Buble et al., 2014).

In turn, Decoene and Bruggeman (2006) have investigated the relationship between the strategic dimension of motivation (including the development of certain motivational mechanisms) and the organizational effectiveness of the enterprise's head, by using a balanced scorecard. The results of the research conducted by scientists provide an opportunity to obtain information on how the company can improve business performance. At the same time, it has been established that an effective strategic dimension not only motivates the head, but also requires his direct and active participation in the business processes of the enterprise (Decoene and Bruggeman, 2006).

\section{Materials, Research Methods and Results}

Eurostat data have been used within the framework of the disclosure of the scientific article. Such methods of economic analysis as generalization and comparison have been applied for processing statistical data.

The disclosure of the scientific article' subject matter requires an in-depth analysis of relevant statistics. Considering it, it is advisable to pay special attention to the examination and analysis of such key indicators as the occupational level, population's education index, individual level of the population's digital skills, the proportion of people who speak a foreign language, the proportion of people employed and at the same time satisfied with their job. 
An analysis of employment statistics in the countries of the European Union has revealed a fairly high employment rate in EU countries such as Austria, Great Britain, Denmark, Ireland, Luxembourg, Malta, the Netherlands, Germany, Portugal, Hungary, the Czech Republic and Sweden, with the employment rate in the European Union higher than $72 \%$ (Table 1). In contrast to the above-mentioned countries, the lowest employment rates are observed in Greece and Latvia, where employment has declined in recent years.

Table 1. Dynamics of changes in the employment rate of the population (aged 15-64 years) in the countries of the European Union, \%

\begin{tabular}{|c|c|c|c|c|c|c|}
\hline No. & Countries & 2014 & 2015 & 2016 & 2017 & 2018 \\
\hline 1 & Austria & 72,7 & 72,7 & 73,7 & 74,7 & 74,6 \\
\hline 2 & Belgium & 62,6 & 63,2 & 65,2 & 65,8 & 67,2 \\
\hline 3 & Bulgaria & - & - & - & - & 66,1 \\
\hline 4 & Great Britain & 77,9 & 79,1 & 79,2 & 79,8 & 81,5 \\
\hline 5 & Greece & 53,3 & 56,2 & 54,6 & 54,4 & 52,1 \\
\hline 6 & Denmark & 73,8 & 72,9 & 72,4 & 73,3 & 73,5 \\
\hline 7 & Estonia & 71,7 & 66,8 & 71,8 & 76,4 & 68,4 \\
\hline 8 & Ireland & 65,9 & 67,8 & 70,8 & 72,2 & 74,0 \\
\hline 9 & Spain & 56,6 & 60,3 & 62,0 & 64,1 & 65,8 \\
\hline 10 & Italy & 60,1 & 60,8 & 61,0 & 61,3 & 61,6 \\
\hline 11 & Cyprus & 65,6 & 65,4 & 67,1 & 69,6 & 67,7 \\
\hline 12 & Latvia & 62,3 & 62,1 & 75,7 & 63,8 & 56,8 \\
\hline 13 & Lithuania & 76,7 & 57,2 & 66,9 & 72,6 & 70,2 \\
\hline 14 & Luxembourg & 74,0 & 71,8 & 71,7 & 73,6 & 74,6 \\
\hline 15 & Malta & 75,9 & 75,8 & 78,7 & 79,7 & 80,4 \\
\hline 16 & Netherlands & 72,4 & 71,5 & 74,0 & 75,4 & 74,7 \\
\hline 17 & Germany & - & - & - & 77,6 & 78,6 \\
\hline 18 & Poland & 64,2 & 69,7 & 61,4 & 67,8 & 70,6 \\
\hline 19 & Portugal & 73,8 & 75,1 & 76,7 & 80,3 & 80,9 \\
\hline 20 & Romania & - & - & - & - & - \\
\hline 21 & Slovakia & 64,4 & 55,5 & 62,3 & 68,3 & 68,3 \\
\hline 22 & Slovenia & 56,9 & 60,0 & 59,7 & 65,4 & 69,7 \\
\hline 23 & Hungary & 72,5 & 70,5 & 76,9 & 76,4 & 74,3 \\
\hline 24 & Finland & 72,4 & 70,1 & 71,2 & 71,5 & 71,9 \\
\hline 25 & France & 66,9 & 65,9 & 65,6 & 67,3 & 68,9 \\
\hline 26 & Croatia & 57,1 & 61,0 & 64,5 & 70,6 & 71,6 \\
\hline 27 & Czech Republic & 69,2 & 68,5 & 72,6 & 78,4 & 77,6 \\
\hline 28 & Sweden & 74,9 & 75,7 & 76,5 & 77,7 & 79,1 \\
\hline
\end{tabular}

Source: Eurostat (n./d.)

Concerning the level of education in the countries of European Union, on the basis of the analysis of the data of Table 2 , it has been established that the most educated countries, where the education level of the population is in the range of over $40 \%$, there are such countries as Great Britain, Ireland, Cyprus. However, Bulgaria, Italy, Malta, Germany, Portugal, Romania, Slovakia, Hungary, Croatia and the Czech Republic remain the least educated countries in recent years. 
Table 2. Dynamics of change in the education index of the population (aged 15-64 years) in the countries of the European Union, \%

\begin{tabular}{|l|l|l|l|l|l|l|l|}
\hline No. & Countries & 2014 & 2015 & 2016 & 2017 & 2018 & 2019 \\
\hline 1 & Austria & 27,4 & 28,1 & 28,9 & 29,7 & 30,1 & 31,0 \\
\hline 2 & Belgium & 32,6 & 32,7 & 33,2 & 35,6 & 36,0 & 36,2 \\
\hline 3 & Bulgaria & 23,6 & 24,1 & 24,4 & 24,5 & 24,8 & 24,7 \\
\hline 4 & Great Britain & 36,6 & 37,6 & 38,3 & 38,7 & 39,3 & 40,2 \\
\hline 5 & Greece & 24,6 & 25,4 & 26,4 & 27,2 & 27,7 & 27,8 \\
\hline 6 & Denmark & 29,4 & 30,2 & 30,9 & 32,1 & 32,4 & 32,8 \\
\hline 7 & Estonia & 32,6 & 33,3 & 34,1 & 34,7 & 35,9 & 36,2 \\
\hline 8 & Ireland & 38,0 & 39,0 & 39,5 & 40,4 & 40,5 & 40,7 \\
\hline 9 & Spain & 31,7 & 32,1 & 32,7 & 33,2 & 34,0 & 34,9 \\
\hline 10 & Italy & 15,0 & 15,5 & 15,7 & 16,5 & 17,1 & 17,3 \\
\hline 11 & Cyprus & 36,4 & 36,4 & 37,6 & 38,1 & 39,4 & 40,2 \\
\hline 12 & Latvia & 26,9 & 28,1 & 29,5 & 30,0 & 30,1 & 30,7 \\
\hline 13 & Lithuania & 31,4 & 33,2 & 34,1 & 34,8 & 36,1 & 37,4 \\
\hline 14 & Luxembourg & 39,6 & 35,2 & 34,1 & 34,8 & 36,1 & 37,4 \\
\hline 15 & Malta & 19,4 & 19,9 & 20,3 & 22,1 & 24,6 & 25,7 \\
\hline 16 & Netherlands & 29,7 & 30,5 & 31,0 & 32,1 & 33,0 & 33,8 \\
\hline 17 & Germany & 23,2 & 23,8 & 24,4 & 24,8 & 25,2 & 25,7 \\
\hline 18 & Poland & 23,8 & 24,4 & 25,2 & 26,3 & 27,2 & 28,0 \\
\hline 19 & Portugal & 19,7 & 20,7 & 21,5 & 21,7 & 22,5 & 23,6 \\
\hline 20 & Romania & 14,2 & 15,0 & 15,1 & 15,3 & 15,5 & 15,9 \\
\hline 21 & Slovakia & 18,1 & 18,9 & 19,7 & 20,7 & 22,0 & 23,0 \\
\hline 22 & Slovenia & 25,1 & 26,6 & 27,2 & 28,7 & 28,7 & 29,1 \\
\hline 23 & Hungary & 20,2 & 20,9 & 20,6 & 20,9 & 21,7 & 22,4 \\
\hline 24 & Finland & 34,7 & 35,5 & 35,9 & 36,4 & 37,3 & 38,3 \\
\hline 25 & France & 29,8 & 30,4 & 30,9 & 31,4 & 32,8 & 33,4 \\
\hline 26 & Croatia & 18,5 & 19,7 & 20,0 & 20,6 & 22,0 & 22,4 \\
\hline 27 & Czech Republic & 19,1 & 19,8 & 20,6 & 21,4 & 21,7 & 21,5 \\
\hline 28 & Sweden & 32,8 & 34,0 & 35,3 & 36,0 & 37,1 & 37,6 \\
\hline
\end{tabular}

Source: Eurostat (n./d.)

The introduction of scientific, technical and innovative developments in the activities of enterprises sets new requirements for its employees and requires the ability to implement them. In view of this, the proportion of the population that are knowledgeable about information on modern scientific, technical and innovative developments and knows how to use them should constantly grow.

Consequently, during 2016-2019, a significantly high proportion of the population with digital skills was found in such countries of European Union as Austria, Belgium, Great Britain, Denmark, Estonia, Luxembourg, the Netherlands, Germany, Finland, the Czech Republic and Sweden. However, the population of Bulgaria and Romania had a low level of personal digital skills (Table 3).

In recent years, there has been an increase in the proportion of people who speak a foreign language in European Union. Both in 2011 and 2016, a significant proportion of EU population was present in countries such as Bulgaria, Great Britain, Ireland, Portugal, Romania and Hungary (Figure 1). 
Table 3. Dynamics of change in the individual level of digital skills of the population in the countries of the European Union, \% persons

\begin{tabular}{|l|l|l|l|l|l|l|}
\hline No. & Countries & 2015 & 2016 & 2017 & 2018 & 2019 \\
\hline 1 & Austria & 64 & 65 & 67 & - & 66 \\
\hline 2 & Belgium & 60 & 61 & 61 & - & 61 \\
\hline 3 & Bulgaria & 31 & 26 & 29 & - & 29 \\
\hline 4 & Great Britain & 67 & 69 & 71 & - & 74 \\
\hline 5 & Greece & 44 & 46 & 46 & - & 51 \\
\hline 6 & Denmark & 75 & 78 & 71 & - & 70 \\
\hline 7 & Estonia & 65 & 60 & 60 & - & 62 \\
\hline 8 & Ireland & 44 & 44 & 48 & - & 53 \\
\hline 9 & Spain & 54 & 53 & 55 & - & 57 \\
\hline 10 & Italy & 43 & 44 & - & - & 42 \\
\hline 11 & Cyprus & 43 & 43 & 50 & - & 45 \\
\hline 12 & Latvia & 49 & 50 & 48 & - & 43 \\
\hline 13 & Lithuania & 51 & 52 & 55 & - & 56 \\
\hline 14 & Luxembourg & 86 & 86 & 85 & - & 65 \\
\hline 15 & Malta & 53 & 50 & 57 & - & 56 \\
\hline 16 & Netherlands & 72 & 77 & 79 & - & 79 \\
\hline 17 & Germany & 67 & 68 & 68 & - & 70 \\
\hline 18 & Poland & 40 & 44 & 46 & - & 44 \\
\hline 19 & Portugal & 48 & 48 & 50 & - & 52 \\
\hline 20 & Romania & 26 & 28 & 29 & - & 31 \\
\hline 21 & Slovakia & 53 & 55 & 59 & - & - \\
\hline 22 & Slovenia & 51 & 53 & 54 & - & 55 \\
\hline 23 & Hungary & 50 & 51 & 50 & - & 49 \\
\hline 24 & Finland & 74 & 73 & 76 & - & 76 \\
\hline 25 & France & 57 & 56 & 57 & - & 57 \\
\hline 26 & Croatia & 51 & 55 & 41 & - & 53 \\
\hline 27 & Czech Republic & 57 & 54 & 60 & - & 62 \\
\hline 28 & Sweden & 72 & 69 & 77 & - & 72 \\
\hline
\end{tabular}

Source: Eurostat (n./d.)

The dynamics analysis of job satisfaction of employed persons shows that the population of Great Britain, Spain, Germany, Poland and France is very satisfied (Figure 2). At the same time, the proportion of people satisfied with job, including the position of managers (administrators), out of the total number of contented persons is high in Great Britain, Germany and France.

\section{Discussion}

Thus, based on the analysis of such indicators as the employment rate, the population index of education, the individual level of digital skills of the population, the proportion of persons who speak a foreign language, the proportion of persons, who are employed and at the same time satisfied with their job it is advisable to note that the positive trends of these indicators take place in many countries of European Union. It becomes clear that one of the ways to improve the above mentioned indicators is precisely the motivation evinced at the enterprises and organizations for employees and managers. The review and analysis of statistical data has showed that 
motivation is one of the elements for ensuring the success of enterprises and organizations in many countries of European Union. This is also evidenced by the high level of job satisfaction of employed persons, including managers (administrators).

Figure 1. The proportion of persons among the EU population, speaking a foreign language, \%

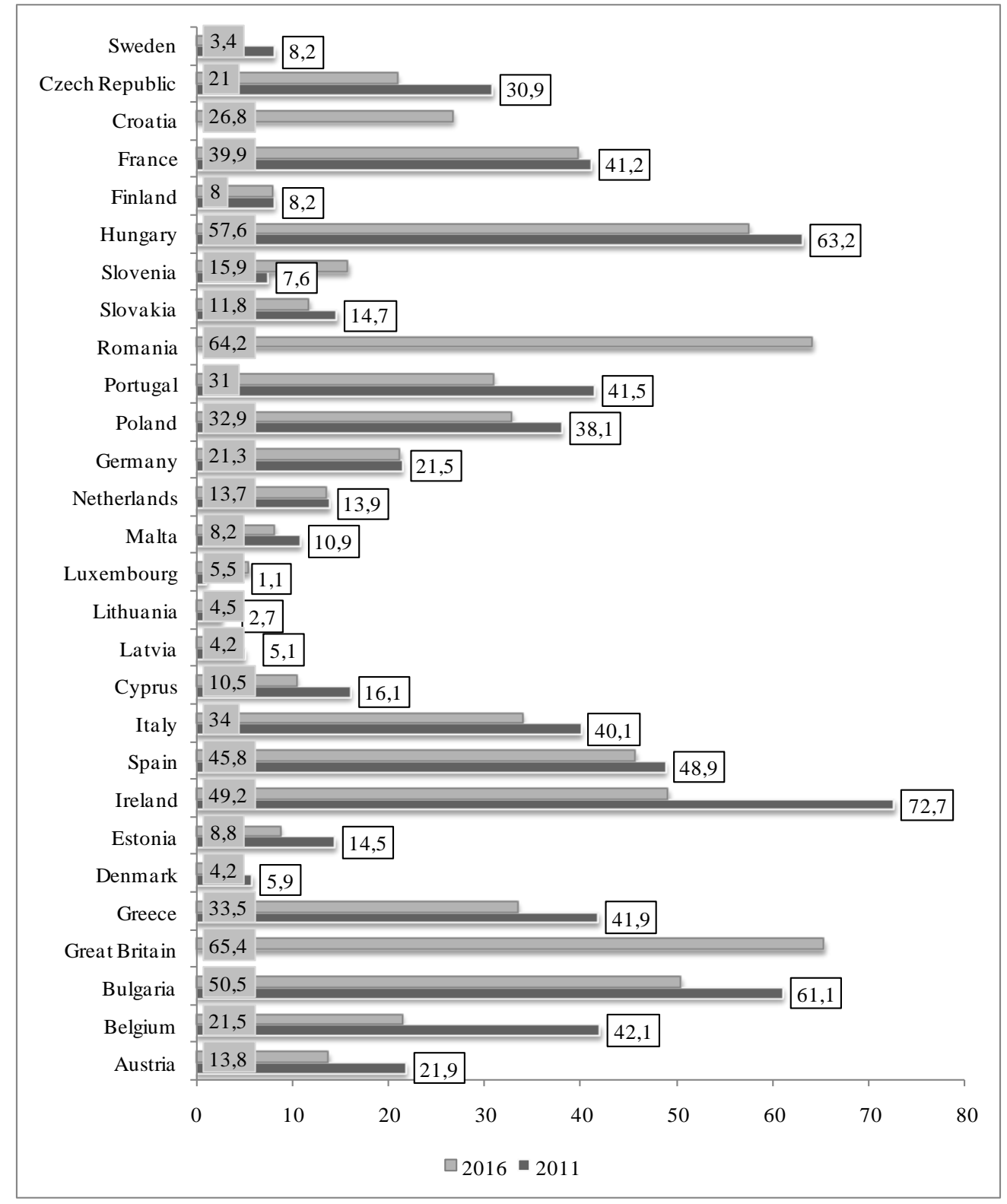

Source: Eurostat (n./d.) 
Figure 2. Dynamics of the number of employed workers, satisfied with the job in 2017, thousand people

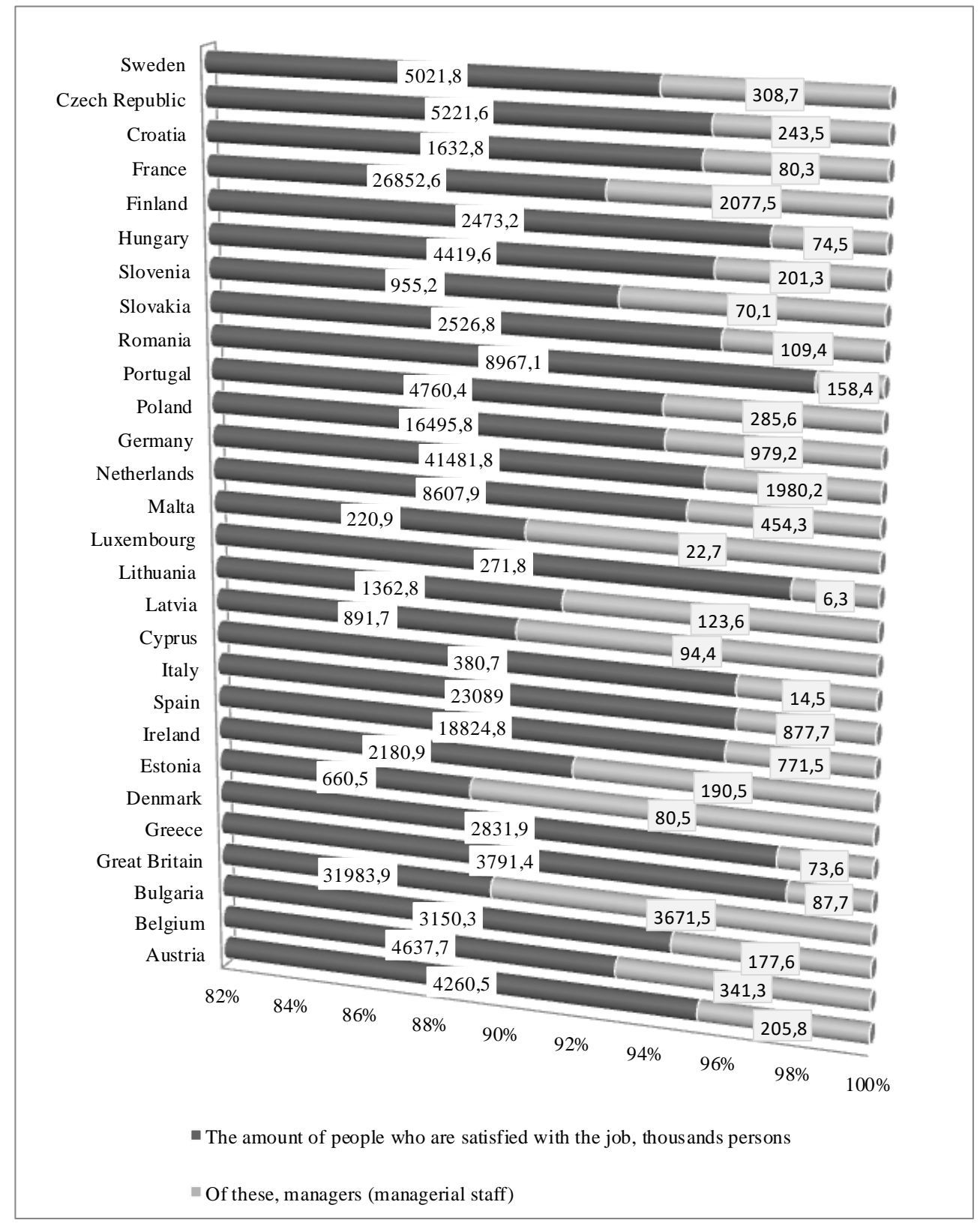

Source: Eurostat (n./d.)

\section{Conclusions}

According to the results of the review conducted and analysis of the theoretical and practical aspects of applying motivation to employees, including to managerial staff 
at the enterprises and organizations of the countries of European Union, it has been established that in Great Britain, Spain, Germany, Poland and France, there is an acceptable, in particular high level of job satisfaction of employed persons, including managers (administrators).

Studies prove that the timely identification and diagnosis of problematic issues that arise on the path of development and growth of enterprises and organizations, significantly depends on the level of qualification and professionalism of the head, that is, the manager.

\section{References:}

Buble, M., Juras, A., Matic, I. 2014. The relationship between managers' leadership styles and motivation. Management, 19, 161-193.

Chromjakova, F. 2016. The key principles of process manager motivation in production and administration processes in an industrial enterprise. Journal of Competitiveness, 8(1), 95-110. https://doi.org/10.7441/joc.2016.01.07.

Decoene, V., Bruggeman, W. 2006. Strategic alignment and middle-level managers' motivation in a balanced scorecard setting. International Journal of Operations \& Production Management, 26(4), 429-448. https://doi.org/10.1108/01443570610650576.

Delmar, F., Wiklund, J. 2008. The effect of small business managers' growth motivation on firm growth: a longitudinal study. Entrepreneurship Theory and Practice, 32(3), 437457.

Eurostat. (n./d.). European statistics. Available at https://ec.europa.eu/eurostat/

Gillan, S.L., Hartzell, J.C., Koch, A., Starks, L.T. 2010. Firms' environmental, social and governance (esg) choices, performance and managerial motivation. Unpublished working paper.

Ke, W., Tan, C.H., Choon-Ling, S., Kwok-Kee, W. 2012. Inducing intrinsic motivation to explore the enterprise system: the supremacy of organizational levers. Journal of Management Information Systems, 29(3), 257-290. https://doi.org/10.2753/MIS07421222290308.

Paglis, L.L., Green, S.G. 2002. Leadership self-efficacy and managers' motivation for leading change. Journal of Organizational Behavior, 23(2), 215-235. https://doi.org/10.1002/job.137.

Li, Q. 2015. The discussion of theory review and practice on enterprise executives incentive. Journal of Human Resource and Sustainability Studies, 3(1), 51-55. https://doi.org/10.4236/jhrss.2015.31008.

Maslen, S., Hopkins, A. 2014. Do incentives work? A qualitative study of managers' motivations in hazardous industries. Safety Science, 70, 419-428. https://doi.org/10.1016/j.ssci.2014.07.008.

Rusetski, A. 2011. Getting proactive: cultural and procedural drivers of managerial motivation to act. Journal of Business \& Economics Research, 9(1), 111-120.

Schmid Mast, M., Hall, J.A., Schmid, P.C. 2010. Wanting to be boss and wanting to be subordinate: effects on performance motivation. Journal of Applied Social Psychology, 40(2), 458-472. https://doi.org/10.1111/j.1559-1816.2009.00582.x.

Wziatek-Stasko, A. 2016. The extent of managers' motivation as a determinant of leadership quality. Economics and Management, 8(1), 37-46. https://doi.org/10.1515/emj-20160004. 